\title{
Factors influencing intention to leave of younger employees in an academic institution
}

\begin{tabular}{|c|c|}
\hline \multicolumn{2}{|c|}{$\begin{array}{l}\text { Authors: } \\
\text { Thapelo D. Chaacha }{ }^{1} \\
\text { Elrie Botha }{ }^{1}\end{array}$} \\
\hline \multicolumn{2}{|c|}{$\begin{array}{l}\text { Affiliations: } \\
{ }^{1} \text { School of Industrial } \\
\text { Psychology and Human } \\
\text { Resource Management, } \\
\text { Faculty of Economic and } \\
\text { Management Sciences, } \\
\text { North-West University, } \\
\text { Vanderbij|park, South Africa }\end{array}$} \\
\hline \multicolumn{2}{|c|}{$\begin{array}{l}\text { Corresponding author: } \\
\text { Thapelo Chaacha, } \\
\text { Thapelo.ChaaCha@nwu.ac.za }\end{array}$} \\
\hline \multicolumn{2}{|c|}{$\begin{array}{l}\text { Dates: } \\
\text { Received: } 19 \text { Nov. } 2020 \\
\text { Accepted: } 06 \text { Oct. } 2021 \\
\text { Published: } 22 \text { Nov. } 2021\end{array}$} \\
\hline \multicolumn{2}{|c|}{$\begin{array}{l}\text { How to cite this article: } \\
\text { Chaacha, T.D., \& Botha, E. } \\
\text { (2021). Factors influencing } \\
\text { intention to leave of younger } \\
\text { employees in an academic } \\
\text { institution. SA Journal of } \\
\text { Human Resource } \\
\text { Management/SA Tydskrif vir } \\
\text { Menslikehulpbronbestuur, } \\
\text { 19(0), a1519. https://doi. } \\
\text { org/10.4102/sajhrm. } \\
\text { v19i0.1519 }\end{array}$} \\
\hline \multicolumn{2}{|c|}{$\begin{array}{l}\text { Copyright: } \\
\text { (C) 2021. The Authors. } \\
\text { Licensee: AOSIS. This w } \\
\text { is licensed under the } \\
\text { Creative Commons } \\
\text { Attribution License. }\end{array}$} \\
\hline \multicolumn{2}{|c|}{ Read online: } \\
\hline 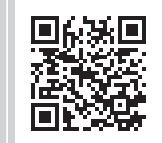 & $\begin{array}{l}\text { Scan this QR } \\
\text { code with your } \\
\text { smart phone or } \\
\text { mobile device } \\
\text { to read online. }\end{array}$ \\
\hline
\end{tabular}

Orientation: The retirement age of most of the academics currently in the workforce is approaching fast. To understand factors that would influence younger academics to leave the profession is becoming more important in order for institutions to avoid a knowledge gap and ensure information and skill transfer.

Research purpose: The purpose of the study was to investigate factors influencing the intention to leave younger employees in an academic institution. The objective was to explore factors that would result in younger employees leaving the institution.

Motivation for study: It is important to understand how younger employees experience the academic world in order to attract, develop and retain them within academia as employees.

Research design, approach and method: Purposive sampling was utilised, which provided the researcher the opportunity to gain further understanding on participants whilst exploring their experiences. The participants were under the age of 35 years, either in possession of a master's degree or in the process of obtaining a master's degree. A thematic analysis was conducted after 17 semi-structured interviews were completed and transcribed.

Main findings: The study revealed that employment practices are the leading reason for the intention to leave of younger academics followed by job satisfaction. Further reasons why employees considered leaving the institution were work engagement and well-being. These findings can assist in developing effective methods of attracting, managing, engaging and retaining these younger employees in the academic institution.

Practical/managerial implications: The results of this study provide insights into human resource management practices to better manage and design methods to reduce younger academics' intention to leave the institution.

Contribution/value-add: Thoroughly exploring factors that can influence younger academics' intention of leaving the profession, meaningful methods to encourage them to stay in these academic institutions could be designed.

Keywords: Academics; human resource management; younger employees; intention to stay; intention to leave.

\section{Introduction}

The central focus of the study is centred on younger employees in an academic institution and their intention to leave. The study focused on employees who are employed as academics, younger than 35 years of age and in possession of a Master's degree or pursing one. Thus it is focusing on exploring reasons that would lead to these employees leaving the academic institution. It is necessary for institutions to retain younger academic employees as the current academic workforce is close to retirement, and knowledge retention is essential for institutional success (Powell, 2010). Younger academics can be seen as the future of academia; it is important to study to retain them in academia as a source of innovation and knowledge retention. The study went further to explore factors that influence these employees to stay within the institution.

\section{Research purpose and objectives}

The main purpose of this study was to investigate the factors that influence the intention to leave younger employees within an academic institution. The study also focuses on which factors would influence these employees to seek alternative employment. 


\section{Literature review}

Academics, in general, play a major role in institutions to be able to thrive in the endless changing world of work. Academic institutions are faced with multiple challenges. One of the major challenges is competition for employees by other sectors (Higher Education South Africa, 2014; Lesenyeho, Barkhuizen, \& Schutte, 2018). In order for institutions to deliver quality results and to achieve their mandate, the retention of academics is crucial (Gunter \& Raghuram, 2018; Pienaar \& Bester, 2008). The importance of reducing and managing the intention to leave of academics is now more important than ever before. Intention to leave is defined as the employees' voluntary decision to leave their current employment by seeking alternative employment (Nadiri \& Tanova, 2010).

These intentions need to be managed as the workforce is ageing and numbers in the student population are increasing (Department of Higher Education, 2016; Higher Education South Africa, 2009). Younger academics fulfil an imperative role in ensuring higher education institutions have the capacity to move forward. The older generation of employees is more experienced, highly qualified and generally seen as more productive and having vast knowledge to offer institutions in higher education (Badat, 2010).

Institutions need to ensure sufficient time and opportunity for more experienced employees to transfer knowledge to younger academic staff. The challenge lies in younger academic staff being offered better rewards by other sectors, which then encourage them to act on their intention to leave and therefore increase high turnover rates (Dube \& Ngulube, 2013). The risk of loose quality in higher education institutions increases if methods to retain employees are not improved (Makondo, 2014). The exchange of knowledge between younger and more experienced groups in academia is important. Similar to other sectors, the academic world globally is becoming more complex; this creates an increasing demand for highly competent employees in this environment (Council on Higher Education [CHE], 2017; Nwadiani \& Akpotu, 2002). The authors are of the view that the majority of previous studies have focused on retaining senior academic staff whilst a limited number of studies focused on young academics. More studies that research these younger academics are therefore necessary to understand them and their antecedents in the academic sphere more comprehensively.

Attracting, managing and retaining diverse employees are challenging as they are influenced by various factors such as remuneration, work-life balance, engagement, autonomy and other employment-related benefits (Samuel \& Chipunza, 2013). Koen (2003) argues that limited financial benefits are the leading reason institutions cannot adequately retain younger academic employees (CHE, 2017). However, this is not the only factor that influences young academics' intention to leave the academic profession. Challenges such as large classes, variety of needs of the diverse student population, underprepared student cohorts, growing regulation of quality assurance adding to the administrative load as well as a publish or perish culture increase the burden academics experience (Cameron \& Woods, 2016). Some of the factors seen to be influencing younger academic employees to leave are discussed below:

Factors such as expectation could influence employees' intention to leave. New recruits into the world of academics have certain expectations, and if these expectations are not met, it might influence them to leave (Islam \& Alam, 2014). Moreover, personal factors such as well-being, family situation and social conditions could also influence employees' intention to leave (Rahman, Naqvi, \& Ramay, 2008). Moloantoa and Darasamy (2017) raise a concern that academic staff might exit the academic environment because of dissatisfaction with work conditions, workload, benefits and remuneration. Thus, job satisfaction is viewed as an important predictor of intention to leave as employees evaluate all aspects of their jobs and if they are not satisfied could increase the likelihood of leaving their jobs. (Amah, 2009; Sypniewska, 2013).

Young academic employees are driven by a sense of achievement, which by recognition of their efforts, could decrease their intention to leave (Chew, 2004; Kwiek, 2017). Work environments that are flexible in their recognition practices and reward structures are more likely to retain academic staff (Ng'ethe, Iravo, \& Namusonge, 2012a). The role of academic leaders is, therefore, to create environments that highlight efforts and support from their managers through recognition, rewards, flexibility and regular feedback (Michael, 2008; Ng'ethe, Iravo, M. E., \& Namusonge, 2012b; Sayers, 2007; Szromek \& Wolniak, 2020).

In general, being included in the decision-making process, doing meaningful work, constant feedback and communication is motivating factor for younger employees (Aruna \& Anitha, 2015; Sissons \& Jones, 2012). These employees take their development seriously. Therefore, a clear career plan is essential to guide them in achieving their goals. Management needs to offer guidance and support to these younger employees (Kim \& Yang, 2013).

Furthermore, young academic employees are motivated by factors, such as opportunities for development and promotion to stay in the academic environment (Mabaso \& Dlamini, 2018; Netswera, Rankhumise, \& Mavundla, 2005). Lesenyeho et al. (2018) found that career development and advancement, as well as opportunities to contribute, attract early career academics. Although academic institutions need to equip these employees with the necessary skills to perform their jobs (Mapesela \& Strydom, 2004; Matongolo, Kasekende, \& Mafabi, 2018), younger academic employees also have the responsibility to ensure that they are capable of achieving success in their roles. Employees with low self-efficacy are generally seen as having a higher intent to leave (Peterson, 2009).

Dedicated employees with low levels of intent to leave seem to be people who have the ability to perform in their roles. 
Therefore, it is imperative that methods are developed to train and retain these employees (Simons \& Buitendach, 2013). Professional development in higher education requires a variety of knowledge and expertise (Cameron \& Woods, 2016).

Even though the development of younger academic employees is important, some challenges occur. They experience pressure to complete post-graduate studies at different levels of their careers to gain promotion. The burden of administrative processes on academics, in general, is seen as a factor that causes a loss of autonomy in their roles (Cameron \& Woods, 2016; Kogan \& Teichler, 2007). Factors such as external funding and integrating online learning are nowadays considered part of the academic profile (Clarke, Hyde, \& Drennan, 2013).

Academic job roles are no longer limited to teaching, research and community involvement.

Even though the above-mentioned factors add to the challenges experienced by the younger academics, institutions have to ensure that these employees are provided sufficient training and development to ensure that they are able to perform in their roles (Chew, 2004). Öldalen, Brommesson, Erlingsson, Schaffer and Fogelgren (2018) argued for the professionalisation of teaching in higher education. These researchers found that academics with less than three years of experience rated pedagogical training very useful.

The sustainability of academic institutions rests on preparing adequate talent for the future. The South African government has developed the New Generation of Academics Programme (nGAP) to address the possible challenges that might arise in terms of a shortage of skills in academia (Department of Higher Education and Training, 2015). The programme outlines what is expected of the incumbent as well as the responsibilities of the new academic. It also refers to the university in which the role will be performed. The programme is designed to gradually develop the new academic through activities such as teaching and research and related aspects. The new employees will be provided with an experienced mentor to ensure that the programme is completed successfully. The researchers view the programme as a proactive move by the government to make academia more attractive to younger employees. Especially as there is competition from other sectors for some of these potential employees who qualify to work in the academic environment. Such a programme is important but can become obsolete if factors that influence younger academics are not explored and managed in time.

Henceforth, this study focuses on factors that influence younger academic employees to leave their current jobs. There is limited research on the phenomenon, as literature focuses mostly on academic employees, in general, or support staff. However, few studies concentrate on younger academic employees. The study takes an exploratory view to examine these factors, as some new factors might become apparent through the research. It is important to discover these factors as younger academic employees are important to the existence of academic institutions and the future of education in the country.

\section{Research design Research approach}

The research is qualitative, as this method of research entails exploring and understanding the meaning behind the experiences of participants (Bryman, 2016; Silverman \& Marvasti, 2008). A qualitative method enables the researcher to describe, explain and unpack experiences of participants (Leavy, 2014), thus allowing the researcher to examine new concepts or thoughts that might arise (O'Reilly \& Kiyimba, 2015). A phenomenological approach was utilised in the research to allow the researcher to gain a better understanding of the participants' experiences from an objective perspective (Starks \& Trinidad, 2007). Phenomenology is critical in assisting the participants to describe their experiences (Grbich, 2013). To better understand the meaning ascribed to these experiences, semi-structured interviews were used to aid participants to share their experiences with the researcher.

\section{Research participants and sampling methods}

Purposive sampling was utilised to identify potential participants for the research. Purposive sampling is done with a specific objective in mind and is therefore particulary successful (Palys, 2008). Purposive sampling is done with specific characteristics of participants as qualifying criteria because of the nature of inquiry of the research (Etikan, Musa, \& Alkassim, 2016). Purposive sampling is essential in the study as it allowed the researchers to meet the main purpose of the study and allowed for variety within the sample to ensure that participants met the inclusion criteria for the research (Bryman \& Bell, 2017).

A target population of $(n=12)$ participants was originally determined by the researchers. However, a total number of ( $n=17$ ) participants were interviewed because of the availability of employees that were willing to participate in the research. The researchers deemed it ethical not to exclude willing participants even though data saturation was met.

Participants were characterised as follows: They were younger than 35 years, in a lecturing or junior lecturing position, and either in possession of a master's degree or in the process of obtaining a master's degree. The participants included both female and male employees from various campuses, faculties and schools to gain in-depth knowledge about the intention to leave of younger academics at the institution.

Permission to contact participants was granted by the institution. Formal emails were sent to recruit participants as interested participants could respond. Firstly, consent was obtained from participants to continue with the research. Thereafter interviews were set up with participants. The researchers could draw specific information about the 
phenomenon being investigated as the participants were well informed about the topic of interest and, therefore, shared knowledge and experience regarding the topic under investigation with the researchers. The ethical process required only interviewing participants willing to participate in the research.

\section{Research procedure}

Semi-structured interviews were conducted with 17 participants across the institution. Audio recordings of the semi-structured interviews were made in aid of transcription and coding. All recordings were stored electronically on a password-encrypted device. Participants were allowed to raise any questions or concerns through the research leader, and all matters were addressed. Ethical conduct was retained throughout the process.

\section{Data collection}

Potential participants were identified through open-source platforms. Recruitment took place through emails inviting them to participate in the research project. To maintain anonymity throughout the research, emails were sent to each participant individually. Participants consented to be audio recorded whilst being interviewed.

The data were protected by ensuring the encryption of devices and documents with passwords. All participants were ensured of confidentiality, anonymity and privacy throughout the process and in future publication of the research.

Semi-structured interviews were conducted by asking specific questions to guide the interview process whilst allowing the participants a degree of freedom to express points of interest (Hesse-Biber, 2017). The process allows participants to comment on aspects that the researchers might not have considered, thereby providing additional information on the research topic. The following interview questions were utilised:

- What factors would influence you to stay in your current job?

- What factors would influence you to leave or seek other employment?

- Probing questions:

- Tell me more.

-What else?

- Could you explain the statement in more detail?

- Are you currently seeking employment elsewhere? Why?

- Is there anything else related to the topic or interview that you would like to ask, comment on or clarify?

\section{Data analysis}

Information gained through the audio-recorded interviews was transcribed. These transcriptions enabled the researchers to code the data. A thematic analysis approach was conducted to allow the researchers to identify, group, analyse and report on findings (Boyatzis, 1998). The thematic analysis involves the required familirisation with the collected data, from which the data could be assigned descriptive codes, to identify recurring themes. The themes were then reviewed and finalised (Clarke, Braun, \& Hayfield, 2015). The thematic process presented an opportunity for the researcher to explore and understand the experiences of the participants (Braun \& Clarke, 2006). The interview questions segmented the coding process and emphasised the intention of the study. Coding can be seen as the process of discovering meaning in specific texts (Hesse-Biber, 2017). The first segment focused on the answers derived from the interview question, What factors would influence you to stay in your current job? The second segment focused on answers derived from the interview question, What factors would influence you to leave, or seek alternative employment? The first level of coding for the first question resulted in 81 ungrouped codes and the second level coding resulted in 18 unique codes. The first level of coding for the second question resulted in 71 ungrouped codes, and the second level of coding resulted in 16 unique codes.

\section{Ethical considerations}

The researchers obtained ethical clearance to conduct the research from the Research Ethics Committee of the university. Participants provided informed consent to be interviewed and audio recorded. Audio recordings are stored on an electronic device that is password encrypted. The primary researcher is the only person who has knowledge of this password. All participants were informed that participation is voluntary and that they could withdraw from the research at any point in time, without any consequences to them. Moreover, participants were made aware of the intended purpose of the research and how information obtained will be utilised. Information was shared with participants with regard to the safe keeping of their information. Participants were assured that all information is treated as confidential and that they will not be identified in any material that will be published.

\section{Results}

The thematic analysis of the data obtains through the 17 semi-structured interviews, provided the following findings. Figure 1 below displays the coded factors that would influence younger academic employees to stay with the institution:

- Environment was found to be the leading reason for these employees to stay in the institution.

- Job satisfaction was ranked as the second important reason for employees to stay in their jobs.

- Whilst rewards and work engagement were the third leading reason for younger academics to stay in the institution.

- Growth and support were found to be the fourth reason that will keep these employees in the institution.

- Opportunity was found to be the fifth reason.

- Social and family dynamics and development are ranked as the sixth motive for younger academic employees to stay in the institution. 
- Furthermore, job security, career progress, interdisciplinary work, general intention to stay, openness, accountability and well-being were found to be some further reasons for younger academic employees to remain with the institution. Interesting to note that employment practices are seen as factors that would generally influence employees to leave, however, respondents indicated that they viewed these practices as factors that, if addressed and improved, would motivate them to stay in the institution.

Table 1 represents the description of the coded factors, as indicated in Figure 1, influencing younger academic employees to stay in the institution.

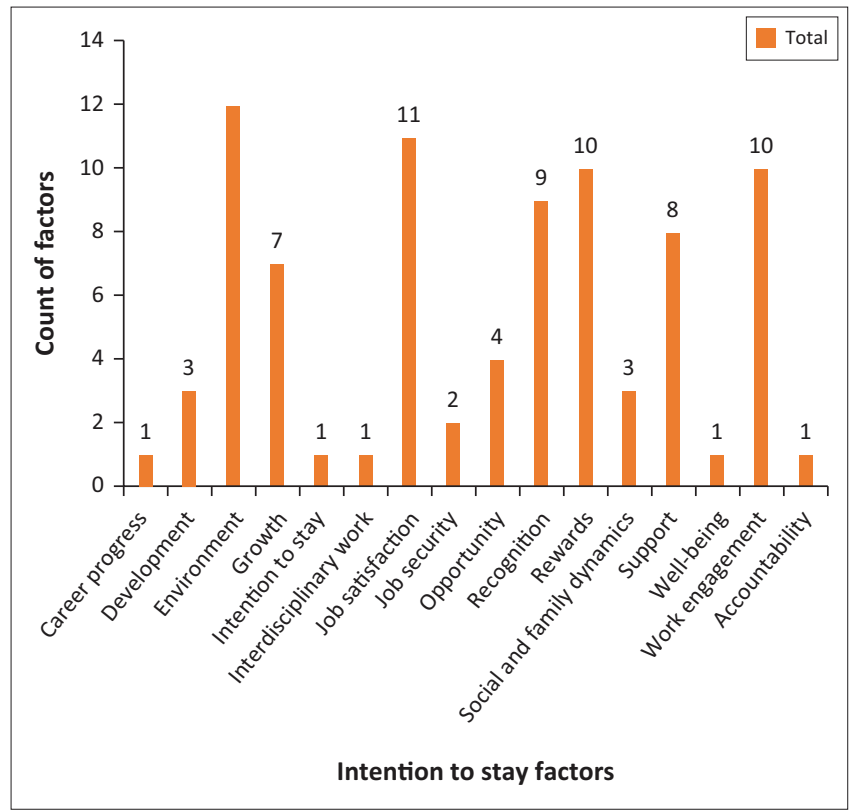

FIGURE 1: Intention to stay factors.
The research aimed to investigate the factors that would influence younger academic employees to leave the institution.

Figure 2 below represents the coded factors that would influence or are influencing younger academic employees to leave the institution:

- Employment practices were found to be the major leading reasons that would influence employees to leave.

- Environment and support are the second most important reasons that would influence employees to leave the institution.

- The third leading factor is the geographical location of the campus.

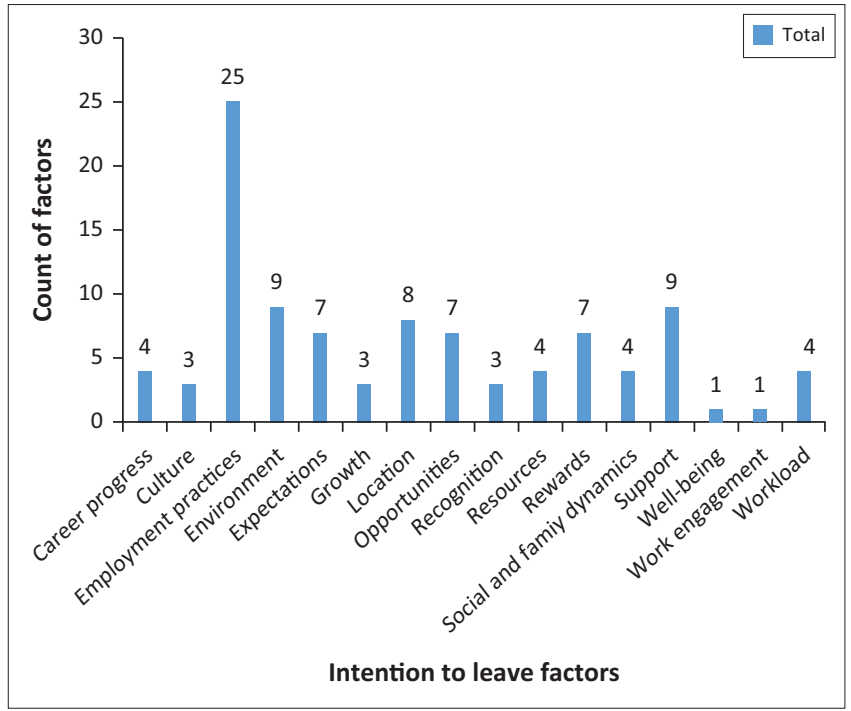

FIGURE 2: Intention to leave factors.

TABLE 1: Description of factors that affect intention to stay.

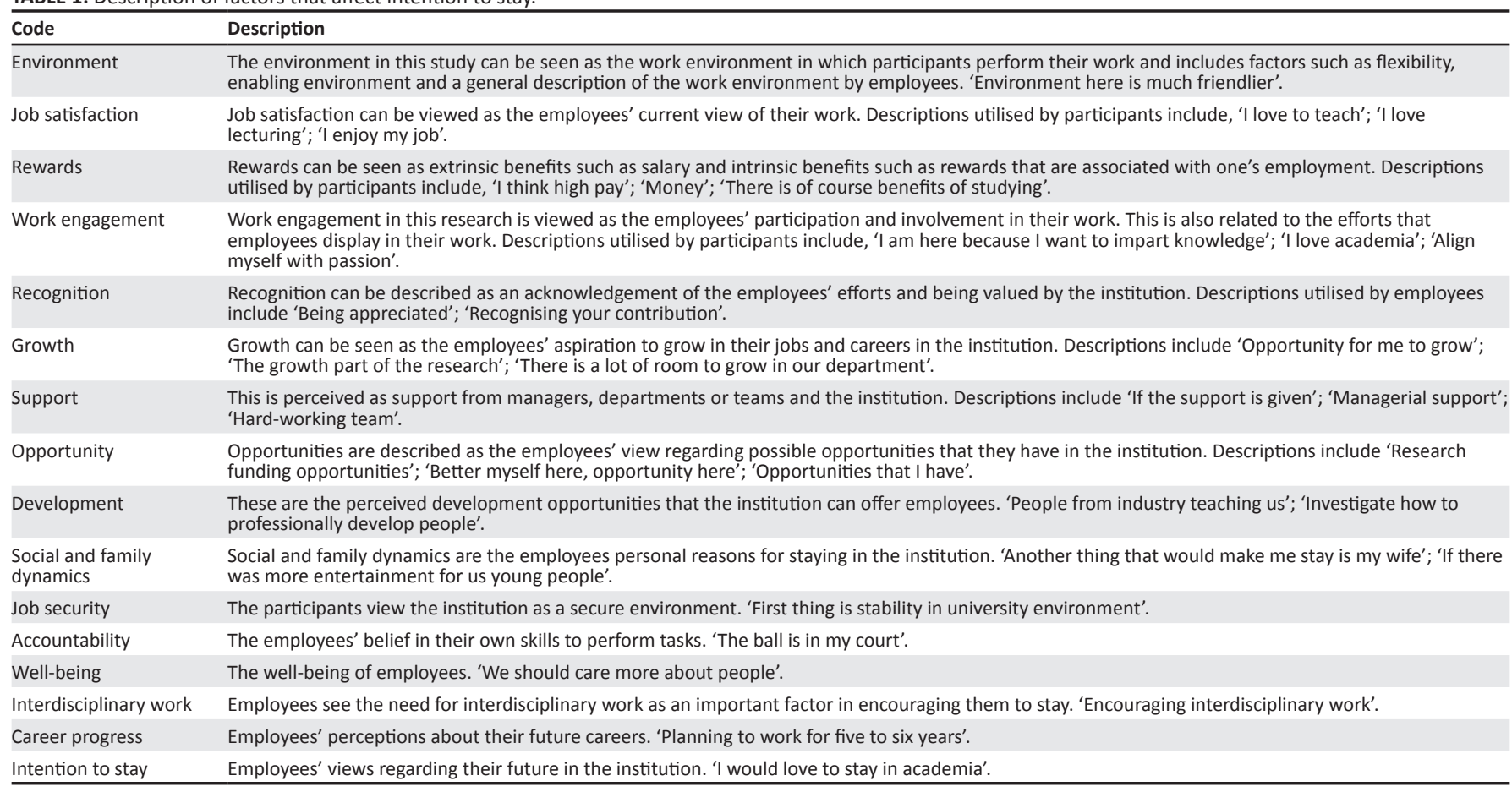


- Expectations, opportunities and rewards are the fourth leading reason for younger academic employees to leave the institution.

- Career progress, resources, workload, social and family dynamics are the fifth reason that was found to influence employees' decisions to leave the institution.

- Culture, growth and recognition are the sixth leading reason that would influence younger academic employees to leave the institution.

- Work engagement and well-being are amongst the other reasons that would influence younger academic employees to leave the institution.

Table 2 represents the description of the coded factors that would influence younger academic employees to stay in the institution, as indicated in Figure 2.

With the focus of the study being the intention to leave of younger academic employees, the following, as indicated in Figure 3, was found. Figure 3 below represents the population of the 17 interviewed research participants. Nine (52\%) employees intend to stay in the institution. It was found that eight $(47 \%)$ participants intend to leave the institution. Three $(37.5 \%)$ of these employees wish to complete their studies before they leave the institution for another sector. Whilst another three (37.5\%) of these employees expressed clear intentions to leave the institution. The remaining two $(25 \%)$ of these eight employees wish to complete their studies before they leave for another institution.

\section{Summary of major findings}

The findings of the study indicate that younger academic employees' intent to leave the institution for various reasons. These reasons include the employment practices that reflect how employees are treated within the institution. Younger academic employees also highlighted the environment as one of the factors that would influence them to leave as the work environment is seen not to be enabling them enough. Lack of support from managers is an influencing factor for some of the employees who intend to leave. However, in contrast to the above-mentioned reasons employees also indicated that they would stay in the institution because of the environment being 'friendly'; other reasons to stay include job satisfaction, rewards and generally being engaged in their work.

\section{Discussion}

The objective of the study was to explore factors influencing the intention of younger academic employees in the institution.

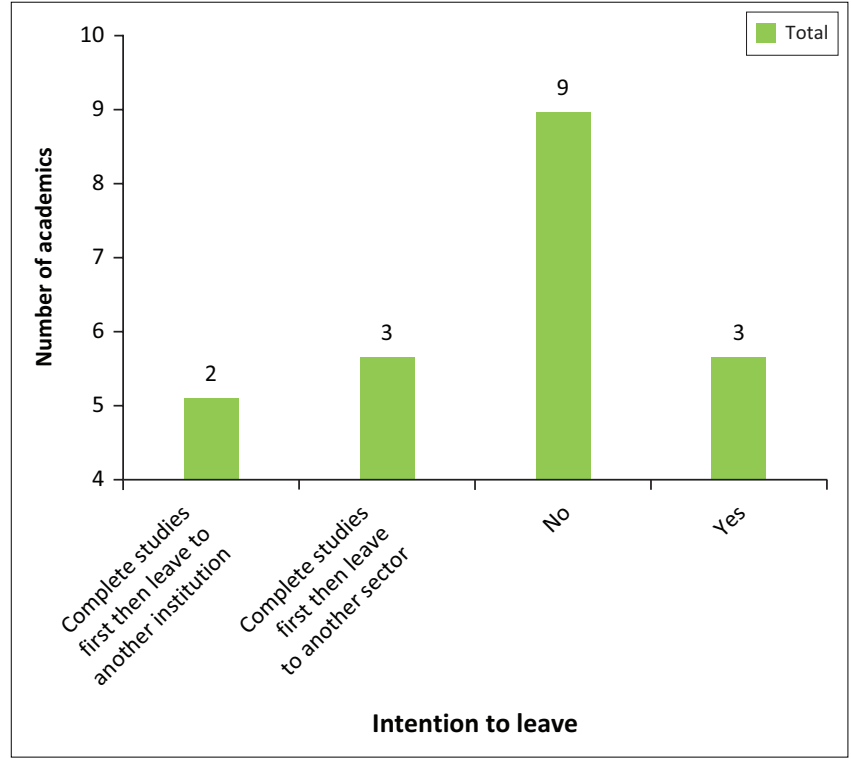

FIGURE 3: Intention to leave.

TABLE 2: Description factors that influence intention to leave.

\begin{tabular}{|c|c|}
\hline Code & Description \\
\hline $\begin{array}{l}\text { Employment } \\
\text { practices }\end{array}$ & $\begin{array}{l}\text { This is viewed as everyday employment issues that employees experience because of how they are treated and how it affects them. Descriptions include 'I've } \\
\text { come to question the integrity of the management'; 'the superior white male figure is really concerning'. }\end{array}$ \\
\hline Environment & $\begin{array}{l}\text { The environment in this project can be seen as the work environment in which participants perform their work and includes factors such as flexibility, enabling } \\
\text { environment and a general description of the work environment by employees. 'For me as a young guy having to do all the crap work'. }\end{array}$ \\
\hline Support & $\begin{array}{l}\text { This is perceived as support from managers, department or team, as well as the institution. Descriptions include 'In the faculty where I work funding is very } \\
\text { limited for junior staff members'; 'Stop giving me so much work so that I can finish my studies'. }\end{array}$ \\
\hline Location & The specific location where the employee is based or area in which the employee lives. Descriptions include 'Firstly the town we are situated in'. \\
\hline Expectations & $\begin{array}{l}\text { The perceived expectations by both managers and employees who are not being met. 'Very attractive, but wait until you get inside and then you realise that yoh.... } \\
\text { this is really not what I signed up for'; 'They are not aligned at all. They are not aligned, because you know. They will be saying we want you guys to be doctors'. }\end{array}$ \\
\hline Opportunities & $\begin{array}{l}\text { Opportunities can be described as the employees' view regarding prospects that they have in the institution or outside the institution. Descriptions include } \\
\text { 'Seeking for better opportunities'; 'When there are opportunities at other institutions'. }\end{array}$ \\
\hline Rewards & $\begin{array}{l}\text { Rewards can be seen as extrinsic benefits such as salary and intrinsic benefits such as rewards that are associated with one's employment. Descriptions include } \\
\text { 'Greener pastures would be more pay'; 'Salary disparities'. }\end{array}$ \\
\hline Career progress & Employees' perceptions about their future careers. 'Scared I would fall behind'. \\
\hline $\begin{array}{l}\text { Social and Family } \\
\text { Dynamics }\end{array}$ & $\begin{array}{l}\text { These factors include the social and personal reasons that would influence the employee to leave the institution. 'They don't care if you have a family and } \\
\text { where your family is'; 'I would leave if I get a position elsewhere closer to my partner, maybe you know'. }\end{array}$ \\
\hline Resources & $\begin{array}{l}\text { These can be viewed as the features that enable employees to perform optimally in their roles. 'They don't care if you have an office'; 'We don't have } \\
\text { equipment'. }\end{array}$ \\
\hline Workload & The amount of work that employees have to achieve. 'The amount of work you have to do is irritating'. \\
\hline Culture & Employees' perspectives on how things are done in the institution. 'I think it's a culture where your input is not considered'. \\
\hline Growth & $\begin{array}{l}\text { Growth can be seen as the employees' aspiration to grow in their jobs and careers beyond the institution. Descriptions include 'I stay in one place forever that } \\
\text { does not mean growth, it doesn't show growth'. }\end{array}$ \\
\hline Recognition & $\begin{array}{l}\text { Recognition can be described as acknowledgement of the employees' efforts and being valued by the institution. Descriptions include 'Because I feel that I am } \\
\text { not valued in that sense'; 'We are made so to speak glorified teachers'. }\end{array}$ \\
\hline Work engagement & $\begin{array}{l}\text { Work engagement in this study is viewed as the employees' participation and involvement in their work. This is also related to the efforts that employees } \\
\text { display in their work. Description 'Not fulfilling'. }\end{array}$ \\
\hline Well-being & The well-being of employees. Description includes 'Your well-being is not considered'. \\
\hline
\end{tabular}


Semi-structured interviews were conducted to investigate these factors, followed by a thematic analysis of the information collected to discover the meanings associated with these factors. Two main segments of the research were analysed, namely factors that would influence younger academic employees to stay in the institution and factors that would influence younger academic employees to leave the institution.

\section{Intention to stay}

\section{Environment}

Based on the findings on intention to stay of the participants, the environment is indicated as the most important reason why these young employees would stay in the academic institution. The environment, for the purpose of this article, is seen as the environment in which employees perform their work and includes factors such as flexibility and an enabling environment, for example, 'Create an environment in which you can follow your dream yourself' and a general description of the work environment by employees. Another reason associated with the environment was openness, as employees value such an environment. Employees generally seek an academic environment that is able to offer them flexible work arrangements, in which they can pursue their goals, where they can have privacy and working conditions, which enable employees to participate in the decision-making process (Beigi, Shirmohammadi, \& Stewart, 2018; Wood \& Wall, 2007).

\section{Job satisfaction}

Job satisfaction was found to be the second leading reason for younger academic staff to stay in the institution. In this article, job satisfaction is viewed as the employees' attitude towards their jobs. The study revealed reasons, such as enjoying being in an academic environment and employees loving their jobs, as job satisfaction factors, for example, 'I am comfortable with the institution and I would prefer not to leave'. Another factor that can be associated with job satisfaction is job security, as employees feel secure about their jobs.

Ssesanga and Garret (2005) indicate that age has a positive correlation with job satisfaction of employees in the teaching fraternity, with older employees being generally satisfied with their salaries, increasing their levels of job satisfaction (Rhodes, 1983; Tulen \& Eyupoglu, 2012).

\section{Rewards}

Participants indicated that another reason affecting their decision to stay was the rewards they receive from the institution, for instance, some indicated salary and others mentioned that they appreciate study benefits offered at the institution, for example, 'Your school should also invest in you'. This indicates satisfaction with both intrinsic and extrinsic rewards offered by the institution as a measure that can be utilised to retain employees (Fallon, 2009; Szromek \& Wolniak, 2020). Of importance is that the rewards offered by the institution are significant to these employees as it aids them in their development as well as allowing both the employer and employee to meet their contractual obligations. Despite these younger employees being the lowest paid, they nonetheless indicate satisfaction with and involvement in their work as an important factor.

\section{Work engagement}

Work engagement is characterised by the employees' involvement in their work. Some employees demonstrated high levels of involvement through their willingness to impart knowledge to students and to participate in the community in which they live, for example, 'Another thing that will make me stay is the research'; 'I have people that actually care about me and that I care for'.

\section{Recognition, growth and support}

The findings of the research reveal that employees require their efforts to be recognised. This demonstrates that the institution needs to value these employees for them to stay, for example, 'Meaning people trusting me with really very difficult responsibility'. This can be linked to the rewards and support received from the institution, as there are different ways in which employees can be recognised, for example, intrinsic and extrinsic rewards, support from management and support from colleagues (Nienaber \& Bussin, 2011). Jawabri (2017) found that low recognition and rewards for work done have a negative influence on job satisfaction of academic staff. Stemming from the findings are factors of growth and support that would keep employees in the institution 'promotion and support for academic growth', 'as long as there is support from the institution'. Growth was seen as the employees' aspiration to grow in their jobs and careers beyond the institution, with employees mentioning prospects such as promotion and the need to advance in research, where support was seen to be received from managers and the institution (Rothmann \& Jordaan, 2006; Turk, 2016).

However, the findings indicate that opportunities need to be available for these employees to grow, suggesting that opportunities presented by the institution can assist employees that are self-effacing to develop.

\section{Social and family dynamics}

Another consideration for employees to stay was the role of social and family dynamics. Reasons provided included personal factors such as family and the social environment in which employees find themselves, for example, 'Perhaps if there was some entertainment for us young people'.

\section{Intention to leave}

The main objective of the study was to investigate factors that would influence employees to leave the institution. The findings of the study are that $47 \%$ of the research sample intends to leave the institution. 


\section{Employment practices}

There are various reasons for young employees intending to leave of which the leading reason being employment practices. For the purpose of the research, it is seen as everyday employment issues that employees experience because of how they are treated and how it affects them, for example, 'A person who has 10 years more than you is going to be treated differently'. Employees' general perceptions included the notion that they are treated differently to older colleagues. In some instances, a perception that employees are treated differently based on their gender influences their decision to leave, for example, 'Women never get promoted here'. Lack of respect from other colleagues was also seen as a determining factor. This is associated with the environment in which employees work, for example, 'You are often seen as incompetent'. Research indicates that dissatisfaction with various factors of employment increases turnover intention (Johari, Yahya, \& Ahmad, 2012).

\section{Environment}

The work environment can be seen as a place in which employees perform their work and includes factors such as flexibility, enabling environment and a general description of the work setting by employees, for example, 'Changes in our working conditions, you know that decisions are made and we just have to comply whether we want to or not'. Participants indicated an environment that is not sociable and culture that is not positive. They indicated the need for a healthier environment enabling growth as some of the environmental factors contributing to their intention to leave (Alzayed \& Murshid, 2017; Ssesanga \& Garret, 2005).

\section{Support}

Employees are influenced by the perceived lack of support from their managers and the institution (Theron, Barkhuizen, \& Du Plessis, 2014). To corroborate this statement, participants cited a lack of funding for junior academics and increased administrative work resulting in limited time for their studies to be completed, for example, 'It's like you are running a sole race in academia'. Others felt that their wellbeing is not considered. This indicates an increased workload that employees cannot manage. As a result of an increased workload, employees feel that their career progress is slow as they fear that their careers will stagnate, for example, 'When you are young here at the university, you are like slave worker', whilst others are motivated to leave to increase career prospects (Bezuidenhout, 2015; Pienaar \& Bester, 2006).

\section{Resources}

Resources are essential to ensure that employees carry out tasks that are required of them. Issues such as the quality of technology utilised, lack of equipment and office space when employees are on-boarded in the institution have influenced these employees' decisions to leave. Employees, for example, stated, 'You cannot do learning with the students because the technology is letting you down'. Beyond this, employees are seeking better opportunities outside the institution (Chen \& Hsieh, 2006; Szromek \& Wolniak, 2020). Some indicated that they would complete their studies first and then leave to go to other institutions, whilst other employees wish to complete their studies and then leave for other sectors.

\section{Growth}

Employees highlighted the lack of growth as another factor that would motivate them to leave, as they view being employed at one workplace for a long period as a lack of growth, for example, 'The main thing generally being stagnating'. Junior lecturers were found to be less satisfied with opportunities, feedback and job enrichment (Jawabri, 2017). Career progress is another factor that would influence these employees to leave, as they do not want to fall behind in their respective fields (Lawton \& Chernyshenko, 2008). This can be linked to employees seeking better opportunities outside the institution, for example, 'If there are opportunities out there, even if it means having to study further elsewhere'. Some employees' intention to leave is influenced by their expectations and their managements' expectations of them being misaligned (Noor, 2011). Other employees are of the view that this is simply not what they expected or signed up for, as the job is completely different to what was advertised, for example, 'I just feel that the job that is advertised is not actually the one'.

\section{Rewards and recognition}

Rewards received by the participants also contributed to their intention to leave as they feel that their needs not being met. Some seek flexible financial support and others generally seek better pay (Grobler, Warnich, Carrell, Elbert, \& Hatfield, 2011). Employees, for instance, stated, 'Moneywise, I wish to go any time'. The lack of recognition of these employees resulted in them feeling undervalued and viewing themselves as only being important when management requires them to perform specific tasks (Theron et al., 2014). Employees stated the following about recognition:

'Management only talk to you when they want something or
want you to do something. It's not simple, you know. I would
appreciate it if the management would send me an email to say
happy birthday, or just telling you that you are doing a good job
but they only communicate with you when the want something.'
(Participant 16)

Another reason that stood out is the geographical location in which some employees were situated that was seen as influencing the intention to leave, as employees longed for a more serviceable town. It should, however, be stated that these employees were mostly satisfied with their jobs. Employees generally complained about basic services such as medical care, the schooling environment for their dependents and a lack of social activities for younger employees progressively affecting their social lives and 
family dynamics increasing their intention to leave, 'So it's more about the city itself, it's not about the job'.

\section{Limitations}

The study presented a few limitations. The institution consists of three different campuses in different locations; this in itself means that the experiences shared by participants are subjective to their respective campus. The effect of this is that there is limited consensus on practices described by employees, as practices and experiences are campus specific. Another limitation of the study is that a population of $n=17$ was interviewed, thus not representing the views of the majority of the younger academic staff profile.

With the study being limited to a one age group, it was challenging for the authors to source supporting literature on younger academic staff. Some employees might have experienced a bit of discomfort being audio recorded by the researcher, even though they had initially consented to this. The principal researcher, who is an academic staff member of the institution, belongs to Bthe category of participants being researched. This might have limited participants in openly taking part. Participants were made aware of the researcher's position. However, objectivity was maintained throughout the process, as the researcher was vigilant to uphold ethical conduct.

Qualitative research limitations for this specific study are that the majority sample of the study population is not represented. Even though the purpose was to obtain rich data if makes it difficult to generalise the findings of the study.

The data analysed is open to subjectivity by the researcher, as it is not measured against a specific item (Creswell, 1994; Mohajan, 2018).

\section{Recommendations and managerial implications}

Based on the findings of the research, $47 \%$ of the participants indicated an intention to leave the instution. It is therefore recommended that the institution pay more attention to younger academic employees. The institution can firstly conduct campus-focused research to address issues that can be resolved immediately in the institutional framework.

Management has the responsibility to manage daily activities, such as the perceived lack of respect from other employees and how younger academic employees are treated. Proactive approaches and policies such as research funding and strategic administrative support can be offered and implemented to reduce the workload of these individuals. Reduced workloads for employees will increase their wellbeing whilst providing resources for employees to perform their tasks will enable them to grow in their roles and respective fields. Employees are generally seeking better opportunities. The institution must create opportunities for the employees, such as consulting work outside the institution, exposure to networking with individuals outside the academic environment for learning and growth purposes and opportunities for interdisciplinary work with colleagues in the institution.

An environment fostering growth is necessary to avoid redundancy as junior employees seek growth and new challenges. A review of growth needs should therefore be conducted timeously to align expectations of both the employee and the institution. Younger academic employees value various forms of recognition - not just financial recognition but also recognition in the sense that their contributions are appreciated and acknowledged by the institution, being allowed to participate in decision-making regarding matters that affect their work and being involved in tasks that are meaningful to them. The recognition of employees includes rewards, as some employees seek better pay and added benefits. A flexible reward system, therefore, needs to be established to accommodate employees' needs. The institution needs to conduct further research on generational reward differences and preferences. This will create a better benchmarking system to ensure that employees can be retained.

Employees' needs differ - some younger employees are in the process of establishing their families, provisional employment practices should be considered to accommodate such varying needs.

Employees' engagement levels need to be maintained for them to stay in the institution, as some employees would prefer to leave for another institution.

This indicates that the issue is not with the job but rather with the institution. It is further recommended that the institution engages with local municipalities on how to improve basic services such as medical care, basic education, water and electricity, as well as the management of environmental and social issues and the improvement of community facilities to cater for younger employees, in general.

\section{Trustworthiness and credibility}

Credibility is emphasised in the study. Credibility refers to the factual representation of perspectives and data of participants by the researcher (Polit \& Beck, 2012). The following steps ensured trustworthiness and credibility of the study:

- Literature focusing on the study and industry was consulted to ensure the worthiness of the study.

- All participants in the study met the criteria for interviewing.

- Interviews were audio recorded and safely stored.

- Interview notes were consulted during transcribing and coding.

- First-level coding took place, with theory on related concepts being consulted; this was followed by second- 
level coding to ensure consistency of concepts and credibility of the study.

- All participants were made aware of the fact that the researcher forms part of the population being studied, before and during the interviews.

- The secondary researcher ensured consistency in data interpretation and research processes.

- The authors followed the ethical procedures set by the institution.

\section{Conclusion}

The objective of the study was to explore factors that would influence younger academic employees to leave the institution. The study revealed various reasons that could result in employees leaving. These include employment practices, where management is seen as lacking integrity, and white male superiority is dominant, in an environment in which there is a general lack of respect for young academic employees, inadequate support for these academics to complete their studies, which perpetuates a culture of disregard for employee contributions, a lack of recognition of employees' efforts and well-being, increased workloads, lack of resources to perform optimally and misaligned expectations and the geographical location of the campuses. The need for growth, and better rewards, creates a desire for better opportunities with other institutions and in other sectors. With $47 \%$ of the participants stating that they intend to leave the institution, management and leaders have a lot to consider regarding ways to reduce the intention to leave of these employees. It is important to note that $25 \%$ of the participants intend to leave for other institutions. Influences on younger academic employees to stay are an enabling environment, job satisfaction, rewards, work engagement, recognition, growth, support and opportunities that these employees receive. It is therefore imperative that the environment in which these employees work is flexible, not only in terms of working hours but also in terms of recognition of these employees in various approaches that can meet their needs. These employees require support to stay engaged and satisfied with their jobs. Management needs to create opportunities that encourage the growth of these employees to reduce their intention to leave ... Flexible programmes, such as the nGAP, could be developed to assist employees in reaching their goals and achieving success, which in turn will reduce the intention to leave of younger academics. Younger academics are essential for the future sustainability of institutions as they will be leaders of these institutions. Retaining them not only reduces recruitment costs but also increases knowledge retention and critical skills development of these employees during their tenure. It is essential to retain these employees as they can keep updated with modern trends and develop new skills necessary for success in current times and the near future. Institutions can preserve the quality of education by ensuring that the needs of these employees are met in the dynamic changing environment and reap such benefits of employee retention.

\section{Acknowledgements}

The authors would like to acknowledge all the research participants. Research participants remain anonymous for confidentiality and privacy reasons.

\section{Competing interests}

The authors have declared that no competing interest exists.

\section{Author's contributions}

T.D.C. contributed as the primary researcher in the research by conceptualising the project, methodology, analysis, investigation, writing up original draft, visualisation and project administration.

E.B. contributed as the supervisor in this research by ensuring review and editing, project adminsistration, conceptualisation and visualisation of the project.

\section{Funding information}

This research project received no funding from any public, private and non-profit organisations.

\section{Data availability}

The data that support the findings of this study are available from the corresponding author, [T.D.C.], upon reasonable request.

\section{Disclaimer}

The views and opinions expressed in this article are those of the authors and do not necessarily reflect the official policy or position of any affiliated agency of the authors.

\section{References}

Amah, O.E. (2009). Job satisfaction and turnover intention relationship: The moderating effect of job role centrality and life satisfaction. Research and Practice in Human Resource Management, 17(1), 24-35.

Alzayed, M., \& Murshid, M.A. (2017). Factors influencing employees' intention to leave current employment in the Ministry of Information in Kuwait. European Journal of Business and Management, 9(12), 17-31.

Aruna, M., \& Anitha, J. (2015). Employee retention enablers: Generation Y employees. SCMS Journal of Indian Management. A Quarterly Journal, 12(3), 94-103.

Badat, S. (2010). The challenges of transformation in higher education and training Institutions in South Africa. Development Bank of Southern Africa.

Beigi, M., Shirmohammadi, M., \& Stewart, J. (2018). Flexible work arrangements and work-family conflict: A metasynthesis of qualitative studies among academics. Human Resource Development Review, 17(3), 314-336. https://doi.org/10.1177/ 1534484318787628

Bezuidenhout, A. (2015). Implications for academic workload of the changing role of distance educators. Distance Education, 36(2), 246-262. https://doi.org/10.1080/ 01587919.2015 .1055055

Boyatzis, R.E. (1998). Transforming qualitative information: Thematic analysis and code development. Sage.

Braun, V., \& Clarke, V. (2006). Using thematic analysis in psychology. Qualitative Research in Psychology, 3(2), 77-101. https://doi.org/10.1191/1478088706qp063oa

Bryman, A. (2016). Social research methods (5th ed.). Oxford University Press.

Bryman, A., \& Bell, E. (2017). Research methodology. Business and management contexts. Oxford University Press.

Cameron, A., \& Woods, C. (2016). A proposed 'Ladder of Learning' for academics professional development in teaching. South African Journal of Higher Education 3(6), 176-190. https://doi.org/10.20853/306732

Chen, H., \& Hsieh, Y. (2006). Key trends of the total reward system in the 21st century. Compensation and Benefits Review, 38(6), 64-70. https://doi.org/10.1177/ 0886368706292542 
Chew, J.C. (2004). The influence of human resource management practices on the retention of core employees of Australian organisations. Doctoral thesis, Murdoch
University. Retrieved from http://researchrepository.murdoch.edu.au/id/ University.

Clarke, M., Hyde, A., \& Drennan, J. (2013). The changing academy - The changing academic profession in international comparative perspective. In B.M. Kehm \& $\mathrm{U}$. Teichler (Eds.), The academic profession in Europe: New tasks and new challenges, 5, 8-21.

Clarke, V., Braun, V., \& Hayfield, N. (2015). Thematic analysis. In J.A. Smith (Eds.), Qualitative psychology: A practical guide to research methods (3rd ed., pp. 222-249). Sage.

Council on Higher Education. (2017). Learning to teaching in higher education in South Africa. An investigation into the influences of institutional context on the professional learning of academics in their roles as teachers. Higher Education Monitor 14. Council of Higher Education.

Creswell, J.W. (1994). Research design: Qualitative \& quantitative approaches. Sage.

Department of Higher Education and Training. (2015). Staffing South Africa's universities framework: A comprehensive, transformative approach to developing future generations of academics and building staff capacity. Department of Higher Education and Training.

Department of Higher Education and Training [DHET]. (2016). Policies and Processes for Phases 1 and 2 of the New Generation of Academic Programme (nGAP). [2015/16, 2016/17 Cohorts]. Pretoria: DHET.

Dube, L., \& Ngulube, P. (2013). Pathways for retaining human capital in academic departments of a South African university. SA Journal of Information Management 15(2). Art. \#560, 1-8. https://doi.org/10.4102/sajim.v15i2.560

Etikan, I., Musa, S.A., \& Alkassim, R.A. (2016). Comparison of convenience sampling and purposive sampling. American Journal of Theoretical and Applied Statistics, 5(1), 1-4. https://doi.org.10.11648/j.ajtas.20160501.11

Fallon, T. (2009). Retain and motivate the next generation. Supervision, 70(5), 5-7.

Gunter, A., \& Raghuram, P. (2018). International study in the global south: Linking institutional, staff, student and knowledge mobilities. Globalisation, Societies and Education, 16(2), 192-207. https://doi.org/10.1080/14767724.2017.1401453

Grobler, P.A., Wärnich, S., Carrell, M.R., Elbert, N.F., \& Hatfield, R.D. (2011). Human resource management in South Africa (4th ed.). Cengage Learning.

Grbich, C. (2013). Qualitative data analysis. An introduction. Sage.

Hesse-Biber, S.N. (2017). The practice of qualitative research. Sage.

Higher Education South Africa. (2009). HESA strategic framework for the next 10 years: Pathways to a diverse and effective South African higher education system. Insight, 1, 1-12.

Higher Education South Africa. (2014). Remuneration of academic staff at South Africa universities: A summary of the HESA statistical study on academic remuneration. Higher Education South Africa.

Jawabri, A. (2017). Job satisfaction of academic staff in higher education: Evidence from private universities in UAE. International Journal of Human Resource Studies, from private universities in UAE. International Journal of
7(4), 193-211. https://doi.org/10.5296/ijhrs.v7:4.12029

Islam, M.F., \& Alam, J. (2014). Factors influencing intention to quit or stay in jobs: An empirical study on selected sectors in Bangladesh. Stamford Journal of Business Studies, 6(1).

Johari, J., Yahya, K.K., \& Ahmad, M.N. (2012). Understanding the influence of human resource management practices on intention to stay: Evidence from Malaysia. $3 r d$ International Conference on Business and Economic Research Proceeding, 12-13 March 2012, Golden Flower Hotel, Bandung, Indonesia.

Kim, J., \& Tang, Y.-C. (2013). What can we do to attract and retain young people to our company as we find it difficult to attract employees at all levels? Cornell University.

Koen, C. (2003). Academics. Human Resource Development Review, 501-517. Retrieved from http://hrdwarehouse.hrsc.ac.za/hrd/academics/academics.pdf

Kogan, M. \& Teichler, U. (2007). Key challenges to the academic profession and its interface with management: Some introductory thoughts. In M. Kogan \& $\mathrm{U}$. Teichler (Eds.), Key challenges to academic profession, pp. 9-15. UNESCO forum on higher education research and knowledge, Paris.

Kwiek, M. (2017). A generational divide in the academic profession: A mixed quantitative and qualitative approach to the Polish case. European Educational
ResearchJournal, 16(5),645-669. https://doi.org/10.1177\%2F1474904116689684

Lawton, K.E., \& Chernyshenko, O.S. (2008). Examining determinants of employee benefit preference: Joint effects of personality, work values, and demographics. Asia Pacific Journal of Human Resources, 46(2), 220-240. https://doi. Asia Pacific Journal of Human
org/10.1177/1038411108091759

Leavy, P. (2014). The Oxford handbook of qualitative research. Oxford University Press.

Lesenyeho, D., Barkhuizen, N.E., \& Schutte, N.E. (2018). Factors relating to the attraction of talented early career academics in South African higher education institutions. Journal of Human Resource Management, 16, a910. https://doi. org/10.4102/sajhrm.v16:0.910

Mabaso, C.M., \& Dlamini, B.I. (2018). Total rewards and its effects on organisational commitment in higher education institutions. SA Journal of Human Resource Management, 16(1), 1-8. https://doi.org/10.4102/sajhrm.v16i0.913

Matongolo, A., Kasekende, F., \& Mafabi, S. (2018). Employer branding and talent retention: Perceptions of employees in higher education institutions in Uganda. Industrial and Commercial Training, 5O(5), 217-233. https://doi.org/10.1108/ICT03-2018-0031

Makondo, L. (2014). Academics attraction and retention trends at a South African University. Journal of Sociology and Social Anthropology, 5(2), 169-177. https:// doi.org/10.1080/09766634.2014.11885621
Mapesela, M.L.E., \& Strydom, F. (2004). Performance management of academic staff in South African higher education: A developmental research project. Presented at the OECD Conference on Trends in the Management of Human Resource in Higher the OECD Conference on Trends in the Management of Hum

Michael, S.O. (2008). Using motivational strategy as panacea for employee retention and turnover in selected public and private sector organisations in the Eastern Cape Province of South Africa. Master of Commerce Thesis. University of Fort Hare.

Mohajan, H.K. (2018). Qualitative research methodology in Social Sciences and related subjects. Journal of Economic Development, Environment and People, 7(1), 23-48. https://doi.org/10.26458/jedep.v7i1.571

Moloantoa, M.E., \& Darasamy, N. (2017). Job satisfaction among academic employees in an institution of higher learning. Problems and Perspectives in Management 15(3), 193-200. https://doi.org/10.21511/ppm.15(3-1).2017.03

Nadiri, H., \& Tanova, C. (2010). An investigation of the role of justice in turnover intentions, job satisfaction and organizational citizenship behavior in hospitality industry. International Journal of Hospitality Management, 29(1), 33-41. https:// doi.org/10.1016/j.ijhm.2009.05.001

Netswera, F.G., Rankhumise, E.M., \& Mavundla, T.R. (2005). Employee retention factors for South African higher education institutions: A case study. SA Journal of Human Resource Management, 3(2), 36-40. https://doi.org/10.4102/sajhrm.v3i2.64

Ng'ethe, J.M., Iravo, M.E., \& Namusonge, G.S. (2012a). Determinants of academic staff retention in public universities in Kenya: Empirical review. International Journal of Humanities and Social Science, 2(13), 297-302.

Ng'ethe, J.M., Iravo, M.E., \& Namusonge, G.S. (2012b). Influence of leadership style on academic staff retention in public universities in Kenya: Empirical review. International Journal of Humanities and Social Science, 3(21), 297-302.

Nienaber, R., \& Bussin, M. (2011). Remuneration policy and strategy. In M. Bussin (Ed.), The remuneration handbook for Africa: A practical and informative handbook for managing reward and recognition in Africa. Knowres Publishing.

Noor, K.H. (2011). Work-life balance and intention to leave among academics in Malaysian public higher education institutions. International Journal of Business and Social Science, 2(11), 240-248.

Nwadiani, M., \& Akpotu N.E. (2002). Academic staff turnover in Nigerian universities (1990-1997). Educ, 123(2), 305-312.

Öldalen, J., Brommesson, D., Erlingsson, G., Schaffer, J., \& Fogelgren, M. (2018). Teaching university teachers to become better teachers: The effects of pedagogical training courses of six Swedish universities. Higher Education Research \& Development 38(20), 339-353. https://doi.org/10.1080/07294360.2018.1512955

O'Reilly, M., \& Kiyimba, N. (2015). Advanced qualitative research. A guide to using theory. Sage.

Palys, T. (2008). Purposive sampling. In L.M. Given (Ed.), The Sage encyclopedia of qualitative research methods (pp. 386-389). Sage.

Peterson, J.Z. (2009). Job stress, job satisfaction, and intention to leave among new nurses. PhD thesis. University of Toronto.

Pienaar, C., \& Bester, C. (2006). Die loopbaandilemmas van akademiese personeel verbonde aan ' $n$ veranderende Suid-Afrikaanse hoëronderwysinstelling. Acto Academica, 38(3), 74-95.

Pienaar, C., \& Bester, (2008). The retention of academics in the early career phase. SA Journal of Human Resource Management, 6(2), 31-41. https://doi.org/10.4102/ sajhrm.v6i2.171

Polit, D.F., \& Beck, C.T. (2012). Nursing research: Generating and assessing evidence for nursing practice. Lippincott Williams and Wilkins.

Powell, W.W. (2010). Understanding attrition and predicting employment durations of former staff in a public social service organization. Journal of Social Work, 10 407-435. https://doi.org/10.1177/1468017310369606

Rahman, A.S., Naqvi, M.M., \& Ramay, M.I. (2008). Measuring turnover intention: A study of IT professionals in Pakistan. International Review of Business Research Papers, 4(3), 45-55.

Rhodes, S. (1983). Age-related differences in work attitudes and behaviour: A review and conceptual analysis. Psychological Bulletin, 93(2), 328-367. https://doi. org/10.1037/0033-2909.93.2.328

Rothmann, S., \& Jordaan, G.M.E. (2006). Job demands, job resources and work engagement of academic staff in South African higher education institutions. SA Journal of Industrial Psychology, 32(4), 87-96. https://doi.org/10.4102/sajip. v32i4.247

Samuel, M.O., \& Chipunza, C. (2013). Attrition and retention of senior academics at institutions of higher learning in South Africa: The strategies, complexities and realities. Journal of Social Science, 35(2), 97-109. https://doi.org/10.1080/09718 923.2013.11893151

Sayers, R. (2007). The right staff from X to Y. Library Management, 28(8/9), 474-487. https://doi.org/10.1108/01435120710837765

Silverman, D., \& Marvasti, A. (2008). Doing qualitative research. A comprehensive guide. Sage.

Simons, J.C., \& Buitendach, J.H. (2013). Psychological capital, work engagement, and organisational commitment amongst call center employees in South Africa. SA Journal of Industrial Psychology, 39(2). Art. \#1071, 1-12. https://doi.org/10.4102/ sajip.v.39i2.1071

Sissons, P. \& Jones, K. (2012). Lost in transition? The changing labour market and young people not in employment, education and training. London: Work Foundation.

Ssesanga, K., \& Garrett, R.M. (2005). Job satisfaction of university academics: Perspectives from Uganda. Higher Education, 50, 33-56. https://doi.org/10.1007/ s10734-004-6346-0 
Starks, H., \& Trinidad, S. (2007). Choose your method: A comparison of phenomenology, discourse analysis, and grounded theory. Qualitative health research, 17(10) discourse analysis, and grounded theory. Qualitative heal
1372-1380. http://doi.org/10.1177/1049732307307031

Sypniewska, B.A. (2013). Evaluation of factors influencing job satisfaction ContemporaryEconomics, 8,57-72.https://doi.org/10.1177/1049732307307031

Szromek, A.R., \& Wolniak, R. (2020). Job satisfaction and problems among academic staff in higher education. Sustainability, 12(12), 4865. https://doi.org/10.3390/su12124865

Theron, M., Barkhuizen, N., \& Du Plessis, Y. (2014). Managing the academic talent void Investigating factors in academic turnover and retention in South Africa. SA Journal of Industrial Psychology/SA Tydskrif vir Bedryfsielkunde, 4O(1). Art. \#1117, 1-14.
Tulen, S., \& Eyupoglu, S.Z. (2012). The age and job satisfaction relationship in higher education. Procedia - Social and Behavioral Sciences, 55, 1020-1026. https://doi. org/10.1016/j.sbspro.2012.09.593

Turk, K. (2016). Performance management of academic staff and its effectiveness to teaching and research-ased on the example of Estonian Universities. Trames Journal of the Humanities and Social Sciences, 20(70/65), 1. https://doi. org/10.3176/tr.2016.1.02

Wood, S.J., \& Wall, T.D. (2007). Work enrichment and employee voice in human resource management - Performance studies. The International Journal of Human Resource Management, 18(7), 1335-1372. https://doi.org/10.1080/09585190701394150 